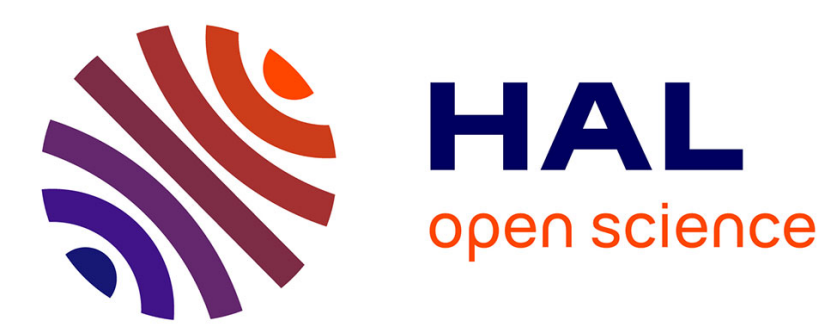

\title{
Stability and formation kinetics of TiN and silicides in the Ti/Si3N4 diffusion couple
}

\author{
M. Paulasto, F. van Loo, J. Kivilahti
}

\section{To cite this version:}

M. Paulasto, F. van Loo, J. Kivilahti. Stability and formation kinetics of TiN and silicides in the Ti/Si3N4 diffusion couple. Journal de Physique IV Proceedings, 1993, 03 (C7), pp.C7-1069-C7-1072. 10.1051/jp4:19937167 . jpa-00251791

\section{HAL Id: jpa-00251791 https://hal.science/jpa-00251791}

Submitted on 1 Jan 1993

HAL is a multi-disciplinary open access archive for the deposit and dissemination of scientific research documents, whether they are published or not. The documents may come from teaching and research institutions in France or abroad, or from public or private research centers.
L'archive ouverte pluridisciplinaire HAL, est destinée au dépôt et à la diffusion de documents scientifiques de niveau recherche, publiés ou non, émanant des établissements d'enseignement et de recherche français ou étrangers, des laboratoires publics ou privés. 


\title{
Stability and formation kinetics of $\mathrm{TiN}$ and silicides in the $\mathbf{T i} / \mathrm{Si}_{3} \mathbf{N}_{4}$ diffusion couple
}

\author{
M. PAULASTO, F.J.J. VAN LOO ${ }^{(1)}$ and J.K. KIVILAHTI \\ Helsinki University of Technology, Dept. of Materials Science and Technology, 02150 Espoo, Finland
}

\begin{abstract}
Reactions in $\mathrm{Ti} / \mathrm{Si}_{3} \mathrm{~N}_{4}$ and $\mathrm{TiN} / \mathrm{Si}$ diffusion couples annealed in the temperature range of $1000-1200^{\circ} \mathrm{C}$ were studied theoretically as well as experimentally with SEM/EPMA technique. Isothermal sections of the Ti-Si-N system were calculated using the most recent thermodynamic data. Calculations showed that TiN and $\mathrm{Si}$ react with each other and form $\mathrm{Si}_{3} \mathrm{~N}_{4}$ and $\mathrm{TiSi}_{2}$, parallel to the experimental studies. Correspondingly, results from the $\mathrm{T} / \mathrm{Si}_{3} \mathrm{~N}_{4}$ couple were in good accordance with calculated phase equilibria.
\end{abstract}

\section{INTRODUCTION}

Silicon nitride is one of the most promising materials among technical ceramics, used in structural components for high temperature applications as well as in electronics industry. Brazing with active filler metals is the preferred method of joining $\mathrm{Si}_{3} \mathrm{~N}_{4}$ to other ceramics and metals. When titanium is present with high activity, it is able to dissociate chemically most stable compounds, and therefore a few percentages of $\mathrm{Ti}$ is commonly added into the filler alloys. Since chemical reactions between $\mathrm{Ti}$ and $\mathrm{Si}_{3} \mathrm{~N}_{4}$ are decisive, e.g. in active brazing, the Ti-Si-N system is one of the most important parts of the brazing system. Thus, a consistent thermodynamic description of the Ti-Si-N system is needed. This description is important also for the studies on the growth kinetics of the reaction products.

Beyers et al. (1) and Schuster et al. (2) have published calculated ternary isotherms of the Ti-Si-N system. In these papers $\mathrm{Ti}_{5} \mathrm{Si}_{3}$ is presented as a line compound and all silicides are in equilibrium with $\mathrm{TiN}_{\mathrm{X}}$. The notable difference between the diagrams is the equilibrium between $\mathrm{TiN}_{\mathrm{X}}$ and $\mathrm{Si}$, which is present in Beyers's diagram but not in the Schuster's one. Wakelkamp (3) has studied the system also experimentally and observed the solubility of nitrogen in $\mathrm{Ti}_{5} \mathrm{Si}_{3}$ to be about 11 at-\%. There is the equilibrium between $\mathrm{TiN}_{\mathrm{X}}$ and $\mathrm{Si}$ in Wakelkamp's diagram, which was determined on the basis of the diffusion couple experiments.

To investigate the system in more detail and to clarify the mentioned omissions and inconsistencies, $\mathrm{Ti} / \mathrm{Si}_{3} \mathrm{~N}_{4}$ and $\mathrm{TiN} / \mathrm{Si}$ diffusion couple experiments were carried out in a high vacuum furnace. The diffusion couples were examined with the SEM/EPMA technique. Since more recent thermodynamic data are now available, the ternary isothermal section of the Ti-Si-N system was assessed using the Thermo-Calc databank system (4).

\section{MULTIPHASE DIFFUSION}

The formation of a phase sequence in a binary diffusion couple can be predicted directly from the relevant phase diagrams. After long annealing all the thermodynamically stable phases will exist as single 
phase regions between the end members - in accordance with the phase rule. Thicknesses of the layers are determined either by linear or parabolic growth kinetics. However, the metal-ceramic systems contain more than two elements, which makes the prediction of the reaction layers much more difficult.

In ternary diffusion couples also two-phase regions can form and therefore many phase sequences are possible. Naturally, diffusion paths in a ternary phase diagram must fulfill the conservation of mass. Since no material can be lost or created the diffusion path is forced to cross the straight line between the end members at least once. Using the model developed by van Loo (5) the actual phase sequence can often be predicted. The central idea in this model is that an element intrinsically diffuses only in the direction of its own decreasing activity.

\section{THERMODYNAMIC DATA AND MODELS}

The Ti-Si-N system was assessed using available thermodynamic data and the Thermo-Calc databank system. The Ti-Si system used in this study was taken from Pajunen et al. (6), which was optimized by using the known lattice stabilities for Ti and $\mathrm{Si}$. The calculated Ti-Si phase diagram is consistent with the results of experimental measurements and optimized parameters have acceptable values as compared with the experimental Gibbs energies of the silicides. The data on $\mathrm{TiN}_{\mathbf{X}}$ were taken from Ohtani and Hillert (7). The Gibbs energy of the formation of $\mathrm{Si}_{3} \mathrm{~N}_{4}$ is given by Hillert et al. (8). The interstitial $\alpha$-Ti and $\beta$-Ti solutions and the nonstoichiometric fcc- $\mathrm{TiN}_{\mathrm{X}}$ were described with the two sublattice model, while the $\mathrm{Ti}_{5} \mathrm{Si}_{3}[\mathrm{~N}]$ solution was modelled with three sublattices (6).

\section{EXPERIMENTAL PROCEDURE}

Two different diffusion couples were prepared: $\mathrm{Ti} / \mathrm{Si}_{3} \mathrm{~N}_{4}$ and $\mathrm{TiN} / \mathrm{Si}$. The high purity (99.99+) titanium and hot-pressed silicon nitride $\left(95 \% \mathrm{Si}_{3} \mathrm{~N}_{4}\right.$, rest $\left.\mathrm{Al}_{2} \mathrm{O}_{3}, \mathrm{Y}_{2} \mathrm{O}_{3}\right)$ specimens were cut from a rod of base material in thickness of about $2.0 \mathrm{~mm}$. After grinding the $\mathrm{Si}_{3} \mathrm{~N}_{4}$ samples were mechanically polished. The titanium samples were polished electrolytically at $-35^{\circ} \mathrm{C}$ and etched subsequently in a $10 \% \mathrm{HF}$ solution. The silicon specimens were cut from (100) single crystal wafers. The titanium nitride films were deposited by reactive ion plating (PVD) on the Si substrates in $\mathrm{Ar}: \mathrm{N}_{2}$ atmosphere. Before the evaporation of titanium the Si-substrates were sputter-cleaned. Microscopical examinations showed that no reaction layer formed during evaporation between the golden-coloured TiN-layer and silicon.

The $\mathrm{Ti} / \mathrm{Si}_{3} \mathrm{~N}_{4}$ diffusion couples were annealed in a vacuum furnace $\left(\mathrm{p}<10^{-5} \mathrm{mbar}\right.$ ) at $1100^{\circ} \mathrm{C}$ for different periods of time. The pressure on the couple's interface was about $350 \mathrm{~N} / \mathrm{cm}^{2}$. The TiN/Si couples were annealed both in a vacuum furnace as well as in vacuum ampoulles at temperatures between 1000 $1200^{\circ} \mathrm{C}$ up to 80 hour. The samples were examined with a scanning electron microscope equipped with WDS-units.

\section{RESULTS AND DISCUSSION}

Figure 1 shows the isothermal section of the Ti-Si-N system and the activity diagram for nitrogen both calculated at $1100^{\circ} \mathrm{C}$. The isotherm is in close agreement with the one determined experimentally by Wakelkamp (3). Due to the solubility of nitrogen $\mathrm{Ti}_{5} \mathrm{Si}_{3}$ becomes in equilibrium with all other silicides. Contrary to Wakelkamp's results the calculated diagram shows an equilibrium between $\mathrm{Si}_{3} \mathrm{~N}_{4}$ and $\mathrm{TiSi}_{2}$ instead of the Si-TiN equilibrium.

\section{Ti/Si3N4 Diffusion joint}

Figure 2a) shows the $\mathrm{SEM}$ micrograph from the interface of the $\mathrm{Ti} / \mathrm{Si}_{3} \mathrm{~N}_{4}$ diffusion couple after annealing at $1100^{\circ} \mathrm{C}$. The joints were invariably fractured along the interface next to the $\mathrm{Si}_{3} \mathrm{~N}_{4}$. The formation of $\mathrm{TiN}_{\mathrm{X}}$, adjacent to the $\mathrm{Si}_{3} \mathrm{~N}_{4}$, in the $\mathrm{Ti} / \mathrm{Si}_{3} \mathrm{~N}_{4}$ couple is suggested earlier in similar studies $(3,9)$. The $\operatorname{TiN}_{X}$ could not be detected in this study and it is likely that the joint has fractured between the $\mathrm{TiN}_{\mathrm{X}}$ layer and the layer consisting of $\mathrm{Ti}_{5} \mathrm{Si}_{3}[\mathrm{~N}]$ and $\alpha-\mathrm{Ti}[\mathrm{N}, \mathrm{Si}]$ solid solution (I in Fig 2a). The qualitative analysis revealed nitrogen in both of these phases. From integral measurements of nitrogen in 


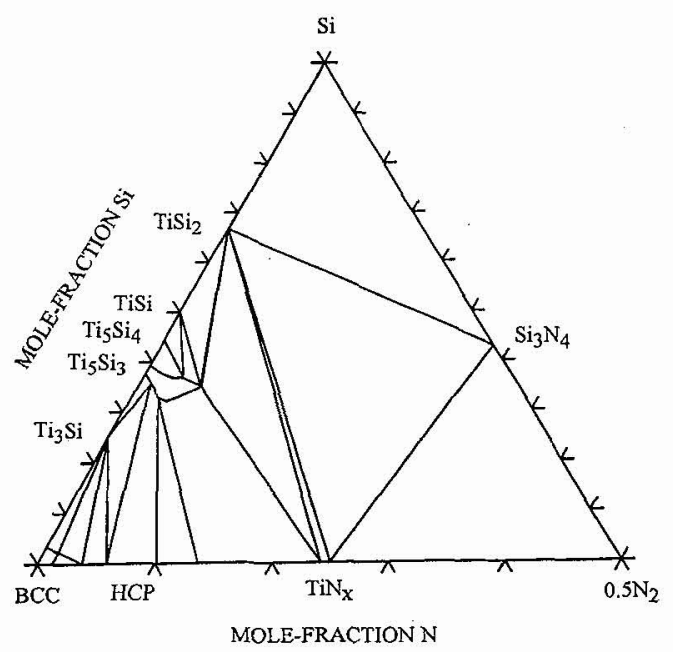

Figure 1 a) Phase diagram of the Ti-Si-N system at $1373 \mathrm{~K}$

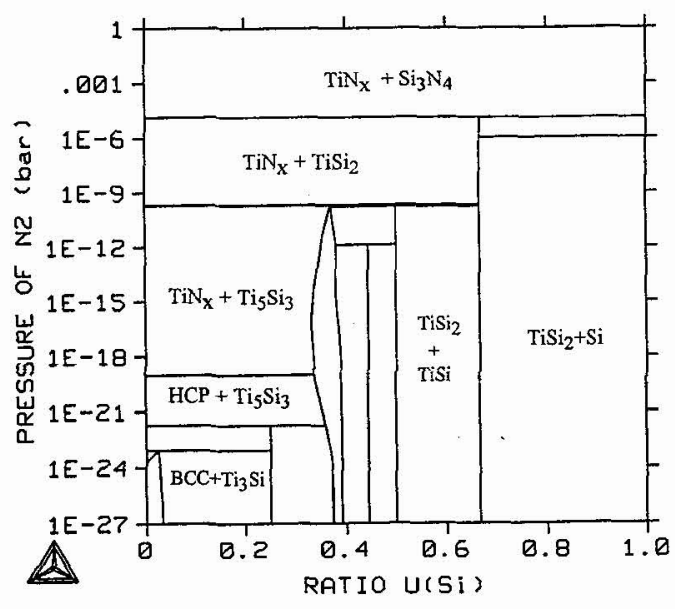

b) Activity of nitrogen $\left(\mathrm{N}_{2}\right)$ as a function of the $\mathrm{u}_{\mathrm{Si}}\left(=\mathrm{x}_{\mathrm{Si}} /\left(\mathrm{x}_{\mathrm{Si}}+\mathrm{x}_{\mathrm{Ti}}\right)\right.$.

$\mathrm{Ti}_{5} \mathrm{Si}_{3}$ with EPMA the solubility of nitrogen in this phase was found to be about 11 at.\% (3). After 40 hours' annealing the reaction layer $\left(\mathrm{Ti}_{5} \mathrm{Si}_{3}[\mathrm{~N}]+\alpha-\mathrm{Ti}[\mathrm{N}, \mathrm{Si}]\right)$ is abt. $29 \mu \mathrm{m}$ thick. The overall reaction layer extends up to $500 \mu \mathrm{m}$ with a wide layer consisting of the $\alpha$-Ti solution and particles of the $\mathrm{Ti}_{5} \mathrm{Si}_{3}[\mathrm{~N}]$ (II in Fig 2a), which are precipitated during cooling. There are also two rows of light coloured $\mathrm{Y}_{2} \mathrm{O}_{3}$ particles (III in Fig 2a). On the basis of the above results the layer sequence is: $\mathrm{Si}_{3} \mathrm{~N}_{4} / \mathrm{TiN}_{\mathrm{X}} / \mathrm{Ti}_{5} \mathrm{Si}_{3}[\mathrm{~N}]+\alpha-$ $\mathrm{Ti}($ prec.) $/ \alpha-\mathrm{Ti} / \beta-\mathrm{Ti}$. The diffusion path is shown in figure $2 \mathrm{~b}$.

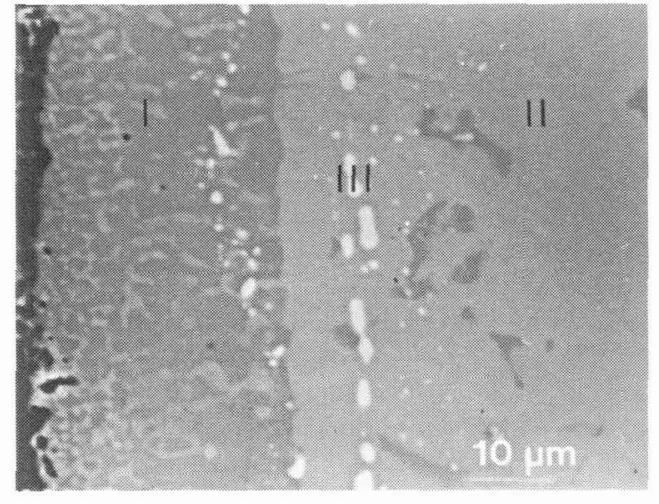

Figure 2 a) SEM-micrograph of the $\mathrm{Ti} / \mathrm{Si}_{3} \mathrm{~N}_{4}$ diffusion couple annealed at $1100^{\circ}$ for 40 hours

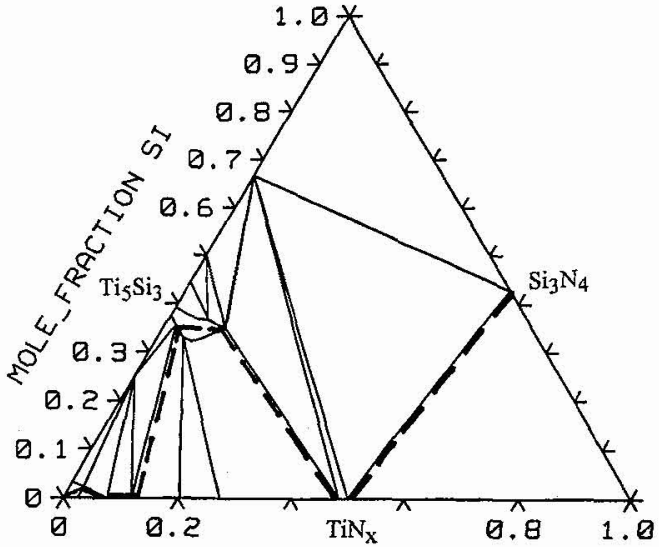

b) diffusion path between $\mathrm{Ti}$ and $\mathrm{Si}_{3} \mathrm{~N}_{4}$ at $1100^{\circ} \mathrm{C}$

\section{TiN/Si Diffusion joint}

After 70 hours' annealing of the TiN/Si couple in vacuum ampoulles at $1100^{\circ} \mathrm{C}$ a thin layer of $\mathrm{TiSi}_{2}$ was formed between TiN and Si, about 1/10 of the thickness of the applied TiN coating of about $6 \mu \mathrm{m}$. It is likely, that the nitrogen released in the reaction dissolves in the TiN solid solution, which might not be fully saturated with $\mathrm{N}$. 
Also in another experiment, made in the vacuum furnace at $1050^{\circ} \mathrm{C}$ for 80 hours, the $\mathrm{TiSi}_{2}$ layer was found next to the silicon (I in Fig 3a). The TiN ${ }_{X}$ layer (II in Fig 3a), originally about $4 \mu \mathrm{m}$ thick, has largely transformed to $\mathrm{Si}_{3} \mathrm{~N}_{4}$ (III in Fig 3a). On the top of the specimen there is a thin layer of $\mathrm{TiSi}_{2}$ (IV in Fig 3a), which is most likely formed in the reaction between TiN and Si in the gas phase. This experiment shows, that under the experimental conditions we worked the phase equilibrium exists between $\mathrm{TiSi}_{2}$ and $\mathrm{Si}_{3} \mathrm{~N}_{4}$ (Fig 3b).

The difference with the results of other investigatiors is presumably caused by impurities, especially oxygen. In principle, it is possible that dissolved oxygen stabilizes $\mathrm{TiN}_{\mathrm{X}}$ and thereby prevents its reaction with silicon. On the other hand, the reaction may be impeded by the presence of a thin $\mathrm{SiO}_{2}$ layer on the silicon, if this is not carefully removed during the experiments. Further experiments are carried out at the moment in order to investigate in more detail the influence of the experimental conditions on the phase relations and the reactions in the $\mathrm{Ti}-\mathrm{Si}-\mathrm{N}$ system.

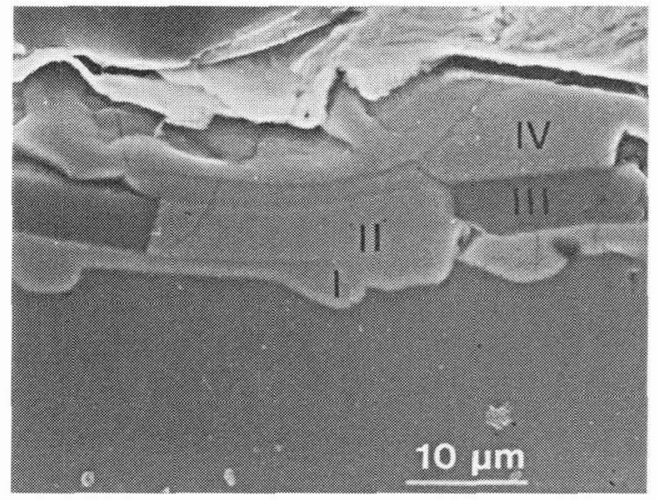

Figure 3 a) SEM-micrograph of the TiN/Si diffusion couple annealed at $1050^{\circ}$ for 80 hours

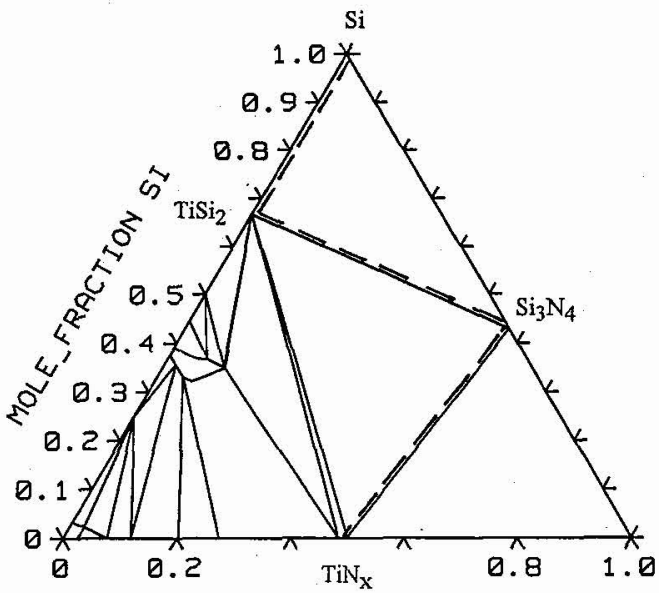

b) diffusion path between $\mathrm{TiN}$ and $\mathrm{Si}$ at $1050^{\circ} \mathrm{C}$

\section{REFERENCES}

[1] Beyers R., Sinclair R. and Thomas M.E., J. Vac. Sci. Technol. B 2 (1984) 4.

[2] Schuster J.C. and Nowotny H., Proc. 11th Plansee Semin. 1 Metallwerk Plansee Reutte (1985) pp.899-911.

[3] Wakelkamp W., Diffusion and Phase Relations in the Systems Ti-Si-C and Ti-Si-N, Doctoral Thesis, Technical University of Eindhoven, 1991.

[4] Sundman B., Jansson B, and Andersson J-O., Calphad 9 (1985).

[5] van Loo F.J.J., Prog. Solid St. Chem. 20 (1990) pp.47-99.

[6]Pajunen M, Kivilahti J. and Miettinen J., Proc. Euromat'89, Aachen, FRG (1989) pp.1055-1060.

[7] Ohtani H.and Hillert M., Calphad, 14 (1990) 3.

[8] Hillert M., Jonsson S. and Sundman B., Z. Metallkd. 83 (1992) 9.

[9] Morgan A.E., Broadbent E.K., Ritz K.N., Sadana D.K. and Burrow B.J., J. Appl. Phys. 64 (1988) 1. 